\title{
Performance Management at Provincial Level in China: A Case Study of Jiangsu
}

\author{
Mengzhong Zhang \\ University of Massachusetts Boston, Boston, USA \\ Hongbin Jiang \\ Jiangsu Government, Jiangsu, China
}

\begin{abstract}
In the first decade of the 21 st century, China experimented with many different kinds of performance measurements and management innovations. However, unlike most provinces in China, Jiangsu pursued two major approaches to implementing performance assessment, during the period of 2003-2009. One is to evaluate the performance of all the prefecture-level city and county governments. The other is to evaluate collective performance of provincial government agencies. The two actions were initially carried out separately but they eventually connected with and complemented each other. Ultimately, they converged on an integrated provincial performance measurement and management picture in Jiangsu. Based on empirical research comprising interviews, seminars, and questionnaires, this study attempts to discover the strengths and weaknesses of the Jiangsu performance management practice. Recommendations of improvement are proposed at the end of the paper. Why has China in general and Jiangsu in particular adopted some kinds of performance measurement system and what benefits can a province reap from such practices? Using Moynihan's theory of the interactive dialogue model of performance information use, the authors use Jiangsu as a showcase of provincial-level government performance management in the hope of paving the preliminary bricks toward building a theory of provincial/state level performance measurement/management.

Keywords: provincial government performance measurement and management, Jiangsu, indicators, theory of the interactive dialogue model
\end{abstract}

In the academic world, there is no general consensus on the definition of "performance measurement". This situation does not prevent us from attempting to capture the essence of the term. Harry P. Hatry stated that "performance measurement has many meanings, but it is defined here as regular measurement of the results (outcomes) and efficiency of services or programs" (Hatry, 2006, p. 3). Kuno Schedler elaborated the performance measurement as:

Set of instrument for a regular and systematic collection of performance data within the production process of the politico-administrative system. These data are refined into expressive management data. Performance measurement (PM) can be compared with financial accounting. The emphasis, however, lies on outputs and outcomes rather than inputs of the process. (Schedler, 1998, p. 1634)

Corresponding author: Mengzhong Zhang, Ph.D., associate professor, Department of Public Policy and Public Affairs, John W. McCormack Graduate School of Policy Studies, University of Massachusetts Boston, Boston, USA; research fields: comparative public administration, comparative administrative reforms, public budgeting and finance, public-private partnerships, performance measurement, public governance.

Hongbin Jiang, master of Public Management, government official in Jiangsu Province, China; research field: performance measurement. 
Kearney and Berman (1999, pp. 1-2) stated that performance "is defined as managing public programs for outcomes", "managers use public resources and mandates to ensure that their programs meet public objectives and expectations". Marr argued that performance is "about identifying, measuring and then managing what matters in order to improve the effectiveness, efficiency, and overall performance of an organization" (Marr, 2009, pp. 1-3). Hatry suggested, "a simple definition of performance measurement for government is the systematic assessment of how well services are being delivered to a community - both how efficiently and effectively" (Hatry, 1980, p. 304). In a broad sense, Bouckaert and Halligan (2008) noted, "span of performance is a horizontal expansion of the results dimension", whereas "depth of performance is a vertical dimension" which consists of three layers: a micro, a meso, and a macro performance. "Micro performance is at the level of an individual public sector organization and its interface with citizens or other organizations. Meso performance is at the level of consistent policy. Finally, macro performance is government wide, or even governance wide" (Bouckaert \& Halligan, 2008, p. 18).

In the United States, the earliest efforts of performance measurement can be traced back to experiments in New York City from 1907 to 1912 (Schedler, 1998). In comparison, the rudimental form of performance measurement practices in China started in the 1980s when "all levels of government implemented efficiency-oriented, objective responsibility systems and efficiency supervision" (Wang \& Rao, 2011). In the area of performance measurement in the public sector, all kinds of performance measurement activities were experimented in China in the first decade of the 21 st century. Public institutions at different levels of governments: central, provincial, and municipal, have demonstrated enthusiasm for performance measurement endeavors.

In recent years, certain new ideas such as accountable government, service-oriented government, rule of law government, have turned into buzzwords among the Chinese academic and practitioner communities. Further, the Chinese government has begun to greatly prioritize a results-oriented performance and customer satisfaction. Under such a backdrop, at the provincial level, Jiangsu government is not an exception but one of the pioneers in pursuing performance measurement for its subordinate city and county governments, as well as its affiliated provincial organizations. In 2003, Jiangsu Provincial Government conceived a set of indicators to evaluate the performance of all the prefecture-level city and county-level governments. The efforts centered on evaluating the outcomes of "a well-off society" including dimensions of economic, social, environmental, and human development within a certain administrative territory. It was from the beginning of 2004 that the indicator system was applied to evaluation action across Jiangsu. Meanwhile, also starting from 2004, Jiangsu Province deployed an annual performance appraisal in provincial agencies. It centered on examining the administrative discipline and work ethic of government employees as well as collective performance of an agency. These two actions were separately carried out but were able to complement each other. Eventually, they were combined into an integrated provincial performance measurement project in Jiangsu.

In short, this paper attempts to study the practice of government performance measurement in Jiangsu as a showcase of provincial level government performance pursuit in China. During recent years, different levels of governments, especially some municipal governments, like Nanjing and Nantong, have introduced and smoothly implemented performance measurement. Chinese experts in public administration are keeping track of these practices. However, there is little emphasis on studying individual projects launched by provincial governments. This paper attempts to fill the literature gap by analyzing the practice of Jiangsu Province.

One important inquiry is: Why did Jiangsu decide to adopt the government performance measurement system and what benefits can the province expect to gain from doing so? The paper attempts to utilize 
Moynihan's theory of the interactive dialogue model of performance information use (Moynihan, 2008) to interpret the partial adoption of performance management reform in Jiangsu. By and large, this paper intends to shed light on the performance management at the provincial level government. By comparing the case of Jiangsu and its counterpart in the USA, the authors hope to pave the preliminary bricks toward building a theory of provincial/state level performance measurement/management.

To this end, this paper consists of seven parts. Part I is the introduction, explaining the research backgrounds, key topics, and research purposes. Part II will briefly review the relevant literatures of performance measurement in the USA and China, including the history, some basic concepts, core values, and major tools of government performance measurement. In Part III, the authors will present their research design. First and foremost, the authors will explain why they decide to do a case study and then why they choose Jiangsu as their case. Then the authors will present their research questions and research methodology. In Part IV, the authors will reveal the findings of Jiangsu practice. In Part V, the authors will summarize and analyze the findings. Accordingly, in Part VI, the authors will propose their recommendations. The authors conclude the paper in the last part.

\section{The International and Domestic Background of Performance Measurement Movement}

\section{The History of the Performance Measurement Movement in the USA}

Woodrow Wilson observed that:

It is the object of administrative study to discover, first, what government can properly and successfully do, and secondly, how it can do these proper things with the utmost possible efficiency and at the least possible cost either of money or of energy. (Wilson, 1887, p. 16)

Performance is closely related to efficiency and cost. In this regard, Wilson's founding study of administration had spread the seeds of performance measurement. The early pioneer of performance measurement can be traced back to the experiments in New York from 1907 to 1912, when Charles Beard led the Bureau of Municipal Research to examine the effect of performance-oriented management (Schedler, 1998; Lynch, 1994).

In the 1940s, Program/Performance Budgeting became incorporated in public management. In 1949, Congress passed amendments to the National Security Act of 1947, which adopted Program/Performance Budgeting in the Defense Department, and in 1950, Congress promulgated the Budgeting and Accounting Procedures Act (originally proposed by the Hoover Commission's 1949 Report), which utilized Program/Performance Budgeting in the remaining agencies (Henry, 2010). Planning-Programming-Budgeting (PPB) system was adopted by the Defense Department in 1961 and President Lyndon B. Johnson ordered PPB to be adopted throughout the federal government in 1965. PPB pays attention to inputs, outputs, effects, and alternatives (Henry, 2010). The PPB practice was abandoned by the federal government in the late 1960s when President Johnson stepped down. In 1973, President Richard Nixon initiated Management by Objective (MBO). In 1977, President Jimmy Carter introduced Zero-Based Budgeting. These initiatives were targeted at improving the quality of federal public services (Wang \& Rao, 2011).

During a March 3, 1993 press conference, Bill Clinton announced the creation of the National Performance Review (NPR) - an interagency task force headed by Al Gore to find new ways to make government less wasteful, more efficient, and more culturally oriented towards performance. The stated principles of NPR were 
strongly aligned with those of new public management, including the elimination of unnecessary levels of bureaucracy, better use of new technologies, delegation of more power to frontline managers and workers, emphasis on improved customer care, and greater communication and collaboration between employees and management. The final NPR report, entitled "From Red Tape to Results: Creating a Government That Works Better and Costs Less", was presented to President Clinton on September 7, 1993. The Government Performance and Results Act (GPRA) was enacted in 1993. The foundation of GPRA is based on the following three elements:

(1) Agencies are required to develop five-year strategic plans that must contain a mission statement for the agency as well as long-term, results-oriented goals covering each of its major functions;

(2) Agencies are required to prepare annual performance plans that establish the performance goals for the applicable fiscal year, a brief description of how these goals are to be met, and a description of how these performance goals can be verified;

(3) Agencies must prepare annual performance reports that review the agency's success or failure in meeting its targeted performance goals.

In 2001, President Bush created the President's Management Agenda (PMA), a plan to "improve the management and performance of the federal government. In the PMA, the President focuses on initiatives where reform is most needed, where there is the greatest opportunity for improvement, and where practical solutions can be readily implemented" [PMA (President's Management Agenda), 2001]. The PMA uses the metaphor of traffic light red, yellow, and green: Red suggests a poor performance; yellow-some progress, and green — good performance of a federal agency. The Bush administration also used Program Assessment Rating Tool (PART) technique to rank the performance of each federal program. "What matters in the end is completion. Performance. Results. Not just making promises, but making good on promises" (Bush, 2001).

The Obama administration has put its own stamp on management and performance reform by focusing on at least four separate initiatives (Joyce, 2011):

(1) Establishing an infrastructure to assess the impact of the American Recovery and Reinvestment Act (ARRA) on jobs;

(2) Identifying a list of programs that should have funding reduced or eliminated because of inadequate performance;

(3) Having agencies established with instruction from the Office of Management and Budget (OMB), "high-priority performance goals";

(4) Committing significant time and resources to program evaluation, in part to assist with identifying what works and what does not.

In the United States, all state governments have conducted some sorts of performance management systems since the 1990s (Moynihan, 2008). The big difference is that some states had earned a grade of "A-" (Louisiana, Missouri, Utah, Virginia, and Washington), while some other states had been given a "C" (Alabama, Alaska, California, Indiana, Montana, New Jersey, North Dakota, Oklahoma, and Wyoming), and two states even obtained a "D" (Hawaii and South Dakota) in 2005 for the management for result assessment by the Government Performance Project (Moynihan, 2008). By 2008, almost all states had collected some forms of performance measurements. But only 39 states require the reporting of performance measurements together with agency budget requests (The National Association of State Budget Officers [NASBO], 2008, p. 57).

Many municipal governments also committed to performance-based budgeting system. Some cities have used systematic performance management processes for decades such as Phoenix, Arizona and Charlotte, North 
Carolina (Wang \& Rao, 2011). The city of Baltimore introduced the CitiStat in 2000 by then Mayor Martin O'Malley (Perez \& Rushing, 2007). In 2004, CitiStat, was one of five winners that were selected from more than 1,000 applicants. Baltimore's computerized system for tracking municipal efficiency has been studied by cities around the country and the world (Vozzella, 2004). In the mid-1990s, New York City Police Department (NYPD) adopted a Compstat system of police management targeted at improved outcomes. From 1993 to 1999, the FBI (Federal Bureau of Investigation)'s total crime index in New York City declined 50\% compared with a drop of $17 \%$ in other major U.S. cities (Smith \& Bratton, 2001).

\section{The Brief History of the Performance Measurement Movement in China}

Chinese scholars appear to agree that the infantile stage of performance measurement in China began in the 1980s (Bao, Chen, \& Jiang, 2008). In the mid-1980s, performance measurement was conducted under the banner of the Objective Responsibility System, which is the Chinese version of MBO. The former Ministry of Labor and Personnel issued an "Announcement of Establishing National Administrative Agency Working Post Responsibility System" in 1982. In 1984, the Central Government brought in a regulation named "Gradually Carrying out the System of Post Responsibility of Government Employees". Under the influence of the internationally popular MBO, the Post Responsibility System developed into the Objective Responsibility System. Until 1998, there were 23 provincial level governments that had adopted MBO for their provincial agencies and more than 100 prefecture level cities practiced the MBO (Bao et al., 2008).

In 1993, the Central Government issued the "Provisional Regulation of Public Servants" (Chinese Public Administrative Society Research Group, 2006). So far, most researchers and government officials have reached the consensus that performance measurement is "an outbreak of administrative reform". Some of them even consider government measurement as the "engine of the new round of government ongoing innovation in China" (Shang, 2009a).

A few researchers focused on historical progress of government performance measurement in China. They stated that during the last three decades, China has witnessed different emphases of performance measurement. In 1980s, it focused on efficiency; in 1990s, it focused on services quality. Starting from the beginning of the 21 st century, government performance measurement has changed into focusing on applying scientific methods to ensure non-biased judgment. One typical way was introducing a third-party into the key process of evaluation to play an independent role. For example, in 2004, Gansu Province entrusted the Evaluation Center of Chinese Local Government Performance Measurement based at Lanzhou University to evaluate 14 municipal governments and 39 provincial government agencies. In 2006, the Siming Administrative District in Xiamen City introduced Bozhi Marketing Investigation Corporation to evaluate public satisfaction with the government performance. Interestingly, also in 2006, Wuhan Municipal Government invited Mckinsey \& Company, the world famous management consultative company, to evaluate the municipal government performance. The general belief is that due to their independent status and neutral standpoint, a third party is likely to make more objective judgment.

Several other methods of scientific performance measurement were undertaken to complement independent evaluators. In 2006, the Balanced Score Card was introduced in a few pilot regions like Hailing City in Heilongjiang Province, Pingshan Town located in Pinnan County in Guangxi Zhuang Autonomous Region, and Wutongqiao District in Leshan, Sichuan Province to adopt this new management method (Bao et al., 2008). In their study of "Provincial Level 'Government Performance Assessment' Model Comparison", 
Zheng and Duan (2012) identified that Fujian had conducted Administrative Efficiency Inspection for the whole province as early as in 1995.

At the Central Government, the study of performance measurement is a recent phenomenon. In July of 2010, the Central Discipline Committee and the Ministry of Supervision had officially established Performance Management Bureau (People's Daily, 2011). In March of 2011, nine organizations [Ministry of Supervision, Central Organization Ministry, Central Establishment Office, State Development and Reform Commission, Ministry of Treasure, Ministry of Human Resources and Social Security (Bureau of Civil Servant), National Audit Administration, National Bureau of Statistics, and Law Office] had formed the Inter-Ministry Government Performance Management Working Conference where the Minister of Supervision Ms. Ma Wen is the convener (Ministry of Supervision, 2011). Under the leadership of the Inter-Ministry Government Performance Management Working Conference, by August of 2012, 27 provincial level governments and more than 20 organizations under the State Council have conducted performance management in one way or another (Ministry of Supervision, 2012).

A research panel from the Chinese Public Administration Society spent substantial time studying performance measurement models existing in China. They suggested that in terms of performance measurement practice, six models could be described: (1) objective management and responsibility model - measuring the real performance against designed goals; (2) quality of public service and customers' satisfaction model - measuring the public services provided by the government; (3) special duty performance measurement model-authoritative government agency measuring specific performance regularly; (4) capacity and efficiency supervision model-implemented by the government supervision agency; (5) comprehensive performance measurement associated with government superintendence model - undertaken directly by the government; and (6) Lanzhou model - performance measured by the third party (Gong, 2006). In terms of the relationship between the evaluator side and the evaluated side (i.e. local government agencies), Chinese Public Administration Society Group concluded that there were four typical models as follows: (1) Siming model, which is characterized by mainly evaluating administrative capacity by insiders; (2) Qingdao model, which is characterized by mainly evaluating objective accomplishment by higher level governments' supervision agency; (3) Zhuhai City's government-dominant opinion poll model; and (4) Gansu model, which is characterized by evaluating economic development by outsiders (Wu, 2008).

\section{Theory Development: Moynihan's Theory of Interactive Dialogue Model of Performance Information Use}

The following are some of the important points and hypotheses of Moynihan's theory of interactive dialogue model of performance information use:

(1) The promise of performance management: claims about improvement. There are a number of promised benefits associated with the recommended reforms of performance management doctrine adopted by governments. Simply stated, governments can harvest the following four categories of benefits: (a) allocate efficiency; (b) accountability of government to the public; (c) accountability of bureaucrats to elected officials; and (d) technical efficiency;

(2) "State governments have mandated that agencies create and disseminate performance reporting requirements, but they have not provided the type of personnel and budgeting flexibility that performance management doctrine suggests is needed. Therefore, we see only a partial adoption of performance management doctrine. In addition, there is little evidence that this information is being used among decision 
makers in the governor's office or in the legislature" (Moynihan, 2008, p. 39);

(3) "The interactive model is based on a number of assumptions: (a) Performance information is not comprehensive; (b) Performance information is ambiguous; (c) Performance information is subjective; (d) Production of performance information does not guarantee use; (e) Institutional affiliation and individual beliefs will affect selection, perception, and presentation of performance information; and (f) The context of dialogue will affect the ability to use performance information to develop solutions" (Moynihan, 2008, p. 102).

\section{Research Design}

There are a number of potential approaches for conducting our study of performance management in China at the province-level. It could be qualitative or quantitative. It could be done by interview, focus groups, questionnaire survey, or other methods. Each method may have its strengths and limitations. Robert K. Yin stated that:

The more that your questions seek to explain some present circumstance (e.g., "how" or "why" some social phenomenon), the more that the case study will be relevant. The method also is relevant the more that your questions require an extensive and "in-depth" description of some social phenomenon. (Yin, 2009, p. 4)

In addition, China is a huge country and has more than 30 provincial units. It would be more suitable to study one provincial unit.

Jiangsu Province is chosen as the authors' case for a number of reasons. Firstly, Jiangsu Province is famous for its performance measurement at the city level. For example, Nanjing City has engaged civic participation in measuring government performance since 2001 (Xie, 2008; Shang, 2009a). In Shang's influential book titled Evaluation Report on the Administrative Performance of China, six models have been cited, and among them two are from Jiangsu Province (Shang, 2009a). Secondly, Jiangsu Province is one of the richest coastal provinces in China. According to Baidu, per capita income of Jiangsu Province has passed 10,000 USD in 2012, higher than any other province in China. Thirdly, as Yin mentioned:

Sometimes, the selection is straightforward because you have chosen to study a unique case whose identity has been known from the outset of your inquiry. Or, you already may know the case you will study because of some special arrangement or access that you have. (Yin, 2009, p. 91)

As it happens, one of the authors is a government employee in Jiangsu so that the authors have easier access to the data.

\section{Research Questions}

This research attempts to analyze the Jiangsu Provincial Government performance measurement practices and focuses on the following questions:

(1) How does the Jiangsu government performance measurement system function?

(2) What indicator system has Jiangsu adopted?

(3) Why did Jiangsu decide to adopt the government performance measurement system and what benefits can the province expect to gain from doing so?

(4) What are the challenges which the Jiangsu project is currently facing and how should policymakers deal with them?

\section{Research Methodology}

For the research methodology, the authors adopted a mixed approach which combines both qualitative 
(interview and seminar) and quantitative (survey questionnaires) methodology. The authors believe this mixed approach is more productive in terms of the validity and comprehensiveness of the result.

Approach 1: Interviewing key figures concerning. The authors interviewed some important people working in the authoritative agencies or inquiring about the internal situation. Some details are as following Table 1.

Table 1

Details of Interviewing

\begin{tabular}{|l|l|l|l|}
\hline Time & Place & Interviewees & Main topics \\
\hline $\begin{array}{l}\text { 9:30 a.m.-10:30 a.m. } \\
\text { April 7, 2010 }\end{array}$ & $\begin{array}{l}\text { Room 312, no. 13 } \\
\text { building, the provincial } \\
\text { government compound }\end{array}$ & $\begin{array}{l}\text { Mr. Yang Qingguo, the vice director of } \\
\text { Special Leading Committee of Jiangsu } \\
\text { Provincial Government Agency } \\
\text { "Administrative Discipline and Work } \\
\text { Ethic" evaluation project }\end{array}$ & $\begin{array}{l}\text { Backgrounds and main processes of } \\
\text { this evaluation project, responses from } \\
\text { the evaluators and the evaluated part to } \\
\text { the project, major progress achieved so } \\
\text { far, etc. }\end{array}$ \\
\hline $\begin{array}{l}\text { 5:00 p.m.-6:20 p.m. } \\
\text { April 17, 2010 }\end{array}$ & $\begin{array}{l}\text { 2nd floor conference } \\
\text { room, no. 9 building, } \\
\text { the provincial } \\
\text { government compound }\end{array}$ & $\begin{array}{l}\text { Mr. Shui Jiayue, the vice Chief Executive } \\
\text { of Jiangsu Provincial Research Office, one } \\
\text { of main designers of the indicator system } \\
\text { to evaluate "welfare society construction" } \\
\text { performance (i.e. the municipal and } \\
\text { county government performance) }\end{array}$ & $\begin{array}{l}\text { Backgrounds of designing the } \\
\text { indicator system, framework of the } \\
\text { problems confronting designers when } \\
\text { drafting and modifying key indicators, } \\
\text { difficulties frustrating the designers } \\
\text { and practitioners when indicators } \\
\text { being put into use, real impacts of the } \\
\text { indicator system, etc. }\end{array}$ \\
\hline
\end{tabular}

On April 7, 2010, the authors interviewed Mr. Yang Qingguo, the vice director of Special Leading Committee of Jiangsu Provincial Government Agency "Administrative Discipline and Work Ethic Construction". It is one pattern of government performance measurement project in Jiangsu. Mr. Yang has been working from the very beginning of initiating this performance measurement program. On April 17, 2010, the authors interviewed Mr. Shui Jiayue, the vice Chief Executive of Jiangsu Provincial Research Office. He is the main designer of the indicator system to evaluate "a well-off society construction" performance, namely the municipal and county government performance.

Approach 2: Questionnaire. According to the main topics and issues, the authors designed a questionnaire consisting of 26 questions (listed in Appendix 1). Respondents had to pick one of six answers for each question. From April 13 to April 20, 2010, the authors distributed 380 questionnaires to several groups of people with diverse backgrounds, including administrators, businessmen, ordinary public servants, and students. Fortunately, with the help of the authors' colleagues, 220 valid questionnaires were collected successfully from government officials who were studying at Jiangsu Provincial Administration School. The 220 respondents represented typical provincial government officials since most of them came directly from the provincial government agencies and others came from municipal and county governments. In particular, although they are at different levels of governments, most of them are in important positions and play influential roles. Moreover, those working in municipal and county government actually came from different parts of Jiangsu and thus represented different regions' interests and attitudes. They should know the government policy and government performance measurement relatively well. A particular group of people are entrepreneurs and middle-level managers working for local state-owned companies. To some extent, they can represent the voice of market actors. In order to cover more people of different backgrounds, 55 questionnaires were distributed to the government officials working in town governments and those working as ordinary public servants in county 
governments across Jiangsu Province. With the help of the authors' friends, another 55 questionnaires were distributed among the ordinary residents living in Xuanwu District of Nanjing City. The last 50 questionnaires were distributed to the graduate students who are studying in Hehai University. By May 11, 2010, the authors got back 361 questionnaires in total out of 380 (see Table 2).

Table 2

Questionnaires Assigned/Got Back

\begin{tabular}{ll}
\hline Total questionnaires assigned & 380 \\
\hline (1) Distributed to the government officials studying in Jiangsu Provincial Administration School in April, 2010 & 220 \\
(2) Distributed to the government officials working at town and county administrative level & 55 \\
(3) Distributed to ordinary residents living in Xuanwu District, Nanjing & 55 \\
(4) Distributed to the graduates students of Hehai University, Nanjing & 50 \\
Valid questionnaires collected & 361
\end{tabular}

Approach 3: Seminar. The authors figured out some relatively confusing questions to solicit proper answers in a well-organized seminar. On May 12, 2010, the authors invited five experts, including three researchers on related subjects, two practitioners working for governments (see Table 3). The authors focused on such topics from a performance measurement perspective. Can the practice of Jiangsu Province be precisely considered as government performance measurement or is it simply a quasi-government performance measurement? What are the creative elements of the Jiangsu practice? What are the advantages? What are its distinctive characteristics? What are the necessary measures which must be taken to modify practice in the future? What aspects should we learn from the successful experience of other provinces as well as Western countries especially USA, etc.? The authors had a very open and constructive discussion. Some of opinions have been reflected in this paper.

Table 3

Details of Seminar

\begin{tabular}{|l|l|l|l|}
\hline Time & Place & Participants & Main topics \\
\hline 3:00 p.m.-5:20 p.m. & $\begin{array}{l}\text { 3rd floor conference } \\
\text { room, Building A, } \\
\text { May 12,2010 }\end{array}$ & $\begin{array}{l}\text { Xu Yijun } \\
\text { Guan Xinhua } \\
\text { Nanjing, Jotiangsu }\end{array}$ & $\begin{array}{l}\text { What is the relationship between Jiangsu practice and normal } \\
\text { Wang Hongfang } \\
\text { performance measurement? What are the unique features and } \\
\text { strengths of Jiangsu practice? Are there any improvements } \\
\text { should be stressed, etc.? What experience could we learn from } \\
\text { the pioneers either in China or abroad, etc.? }\end{array}$ \\
\hline
\end{tabular}

Approach 4: Telephone interview. Because it is a little difficult to meet two important persons living in other cities within this relatively short time, the authors called them when they were free. One is Professor Zang Naikang from Nantong University. He has been keeping track on performance measurement for more than 10 years. He especially knows sufficient information about the practice of performance measurement in Nantong Municipal Government. The other is Professor Tian Zhijian, who works in Suzhou University. He also investigates government management. The authors discussed some issues with them over the phone about the performance measurement in Jiangsu.

\section{Findings From Jiangsu Practice}

In general, Chinese performance measurement system is based on public interests, national subject, and vertical operational structure, whereas American system is based on civic society, commonwealth subject, and mainly horizontal operational structure. What is more, Western countries prefer to apply complicated and detailed indicators, but China prefers to design relatively general indicators (Qi, 2007). 


\section{Particular Relationship Between Performances of Government Agency and Government Officials at Provincial Level in Jiangsu}

In Jiangsu, the provincial government decomposed the performance measurement into two main dimensions: One is concentrated on evaluating the performance of government officials and the other is dedicated to evaluating the outcomes of government policy. This split differentiates the two aspects properly and gives the right direction to make further improvements. Furthermore, it highlights different performance requirements for different actors, namely municipal and county governments and provincial government agencies. Also, it will promote better outcome, more positive encouragement to different evaluations (i.e. the evaluated object), and bring in more flexibility to them in next steps.

If being observed from a performance framework perspective, the provincial government agencies' performance in Jiangsu can be viewed as organizational performance of provincial government; while the municipal and county government performance can be viewed as systematic performance of Jiangsu Provincial Government. Systematic performance is comprehensive and usually has huge impacts on all of society. From a system perspective, the authors can decompose systematic performance into four dimensions: population, society, economy, and environment.

As a whole, Jiangsu Provincial Government performance measurement has two subjects: One is restricted to nearly 100 provincial government agencies. It mainly aims at examining the performance of government employees, emphasizing on their complying with the administrative discipline, professional work style, and work ethic. The other is restricted to 13 prefecture-level city governments and 52 county governments which are directly under the supervision of provincial government. It mainly aims at examining the performance of city and county governments, and the emphasis is focusing on evaluating the outcomes of economic, social, and human development within a certain territory.

\section{Jiangsu Practice One: Features of Performance Measurement in Jiangsu Provincial Government Agencies}

The performance measurement in Jiangsu provincial government agencies started in 2004. From the very beginning of this action, the main goal of performance measurement was expressed very clearly. It aimed at reaching "three changes": changing the mind, changing government accountability, and changing work discipline and work style.

"Changing the mind" centers on "mind emancipation". In other words, the government officials must get rid of the restriction of traditional bureaucracy, outdated notions, and outworn institutions; instead, actively accept modern governing ideas and new notions, like learning from the people as well as serving the people, attaching more importance to the creation of grassroots organizations, consciously making decision on the foundation of the practice, providing more services rather than controlling and restricting, etc. "Changing accountability" means regulating the responsibility of individual agencies to avoid overlapping duties, carrying out the accountability regulated by law, deepening the reform of administrative approval and simplifying the cumbersome procedures, strengthening the number one priority of serving Jiangsu development, etc. "Changing the work discipline and work style" mainly means promoting work discipline and work ethic, specifically, doing investigation before decision making, trusting the people when facing administrative challenges, eliminating red tape, allowing greater involvement of market forces instead of monopolization within government agencies, eradicating corruption and promoting clean politics, etc. 
The main procedures and methods of measurement in Jiangsu provincial government agencies in 2004 can be reflected in eight aspects.

(1) Setting up a special committee to administrate the whole process of performance measurement. The committee assigns tasks annually to all the government agencies. The Provincial Governor acts as the chairman of the committee. A special office is established to do routine jobs, especially mobilizing relevant forces and organizing evaluation activities. The Chief Executive of each government agency must bear the primary responsibility of promoting performance measurement within his or her agency;

(2) Performance measurement centers on evaluating the progress of "three changes". All the performances must be compared with the progress made within one year for the three aspects mentioned above. A set of indicators covering "accountability, efficiency, service, manner, and morality" was designed based on the main goal. According to these indicators, actual grades would be given;

(3) Diverse channels have been put into use in the process of evaluation. The major channels include interviewing the particular recipients of governmental service to find out the real situation, publicizing relevant information in major news media to let more people know about the recent improvement, making use of the Internet to seek public appraisals, inviting the independent survey panels to make investigations, and sending out specially designed questionnaires to no less than ten thousand citizens to inquire about public opinion. In particular, every year the special office will organize thousands of people to scrutinize the government agencies, and give their independent opinions. What is more, the committee decided to set up 13 inspecting offices in 13 municipalities across the whole province. Besides, the office of the committee chose certain counties, towns, villages, communities, and corporations to set up 40 special supervising stations to directly ask for people's opinions. The information collected by these offices would be recognized as the regional opinion coming from the bottom unites of Jiangsu Province;

(4) On the basis of responsibilities, 82 provincial government agencies have been divided into two categories to be evaluated. Among them, 28 are complex responsibility agencies (e.g. the government research office, the complaints bureau, etc.) and 54 are line responsibility agencies (e.g. the health department, the environment department);

(5) The initial judgment to each agency will be given in terms of 100 points by 10 types of evaluators. Different calculation weights are allocated to 10 types of evaluators/inspectors (see Table 4). The final score will be calculated by the initial overall judgment times corresponding weights;

(6) The overall judgment about the provincial government agencies as a whole will be sorted out in three degrees: satisfactory, basically satisfactory, and not satisfactory. Correspondingly, they are assigned different baseline scores to be 90,70, and 50. Meanwhile, the specific judgment about a particular government agency will be mainly sorted out in three conditions including excellent (satisfactory), good (basically satisfactory), and poor (not satisfactory). However, if an evaluator happens to know nothing about the performance of a particular agency, the judgment can be stated as "results not demonstrated". For example, if an evaluator thinks the performance of a particular agency is worthy of "excellent", he can give the score between 90 and 100 . Likewise, if "good", the score will be from 70 to 89 . If "poor", the score will be from 50 to 69. If the judgment is "results not demonstrated", it will be ruled out when calculating the score. In addition, all the evaluators are anonymous which can guarantee them make personal judgment fairly and frankly;

(7) Putting the percentages of excellent (satisfactory) and good (basically satisfactory) together, the provincial government and the special committee will know the exact percentages of each level; 
Table 4

The Types and Numbers of Evaluators (2004)

\begin{tabular}{llll}
\hline \multicolumn{2}{l}{ Ten types of evaluators/inspectors } & \multicolumn{1}{c}{$\begin{array}{c}\text { Weighted } \\
\text { of each type (in 2004) }\end{array}$} \\
\hline 1 & The leaders of provincial government & $11 \%$ & 98 \\
2 & The standing members of executive committee & $10 \%$ & 749 \\
3 & The representatives of provincial congress & $11 \%$ & 1,323 \\
4 & The leaders of municipal governments & $9 \%$ & 349 \\
5 & The leaders of counties and some standing members & $12 \%$ & 1,758 \\
6 & All the leaders and some ordinary officials of provincial government & $11 \%$ & 893 \\
7 & Some officials of core divisions of municipal governments' agencies & $9 \%$ & 1,350 \\
8 & Some officials working in the governments below the county level & $8 \%$ & 2,552 \\
9 & Representatives coming from science, education, entertainment, health, sports, military, etc. & $7 \%$ & 330 \\
10 & Representatives coming from different types of enterprises & $12 \%$ & 1,055 \\
& Representatives in total & & 10,547 \\
\hline
\end{tabular}

Note. Data source: Special office of provincial government performance measurement.

(8) The final result of performance measurement of a particular agency will be connected with the annual evaluation of each leader and public servant working in office, which will be reflected in the form of annual bonuses and honors. To the agencies ranking in the first 10 positions respectively in the two categories (totally 20 agencies), the provincial government and the special evaluating committee will give each agency a special annual reward and honor. On the contrary, to the agency ranking in the last position, the provincial government and the special evaluating committee will publish the organization in the news media and set a deadline of rectification to meet requirements. If one agency happens to rank in the last position for two consecutive years, the Chief Executive of the agency will be removed from his or her original position.

In 2006, the performance measurement in Jiangsu Province changed in some aspects so as to match with the changing reality and new expectations of the public. For example, the provincial government agencies to be evaluated expanded from 82 to 100 . The 100 agencies have been divided into three categories: Twenty-eight are complex responsibility government agencies of Jiangsu Province, 49 are special responsibility government agencies of Jiangsu Province, and 23 are administrative agencies vertically subordinate to the central government. Meanwhile, the evaluators were classified as eight categories, and each category has its certain number of representatives (see Table 5). From this table, we can see one of dramatic changes is that the number of different levels of government organizational leaders decreased considerably. The leaders of provincial government, municipal and county governments were excluded from the evaluators or inspectors except for those who also acted as the members of provincial congress. Meanwhile, for the first time, the representatives coming from the news media stood in the line of evaluators.

The effect of performance measurement in provincial government agencies is obvious. All the agencies were motivated to do their best to improve performance. For example, in 2004, the Industry and Commerce Administration Bureau of Jiangsu eliminated 73 specific requirements of applying for licenses and regular annual inspection. It was widely applauded by enterprises across Jiangsu. Also, efficiency had improved to a great extent. For the agency ranking in the last position, the pressure of improving its performance was especially large. Those agencies ranking in the second-to-last-to-fifth to last positions felt almost the same pressure. For example, because the Transportation Department of Jiangsu was involved in a serious financial corruption scandal in 2004, therefore it was evaluated to be in last place in 2004. After sending the offender to 
the court, they checked up all the procedures concerned and tightened administrative discipline in order to prevent corruptive deeds from happening in that department again. In the following year, the department made tremendous efforts to improve its performance. Almost all the evaluators realized considerable progress made during this period of time. Eventually, the department ranked in the top 10 among all the government agencies.

From overall judgment about the provincial government agencies, the progress resulted from the performance measurement was significant as well. Comparing the result of 2005, 2006 with that of 2004 (i.e. the starting year), we can see that significant improvements have taken place (see Table 6) during this period of time.

Table 5

The Types and Numbers of Evaluators (2006)

\begin{tabular}{lll}
\hline & The evaluators/inspectors & $\begin{array}{l}\text { Numbers of } \\
\text { representatives in each } \\
\text { category }\end{array}$ \\
\hline 1 & The representatives of provincial congress & 2,100 \\
2 & The representatives of ordinary government officials working in the provincial government agencies & 1,200 \\
3 & The representatives of ordinary government officials working in the municipal government agencies & 2,000 \\
4 & The representatives of ordinary government officials working in the county government agencies & 1,600 \\
5 & The representatives of farmers and residents of small city and town & 1,200 \\
6 & Representatives coming from different corporations & 1,500 \\
7 & $\begin{array}{l}\text { Representatives coming from media, science, education, entertainment, health, sports, military, the } \\
\text { branch of central government agencies located in Jiangsu }\end{array}$ & 500 \\
8 & Representatives coming from the inspecting points & 10,600 \\
\hline
\end{tabular}

Note. Data source: Special office of provincial government performance measurement.

Table 6

Overall Evaluation (2004-2006)

\begin{tabular}{llll}
\hline Overall evaluation & 2004 & 2005 & 2006 \\
\hline (1) Satisfactory & $49.77 \%$ & $54.73 \%$ & $58.93 \%$ \\
(2) Basically satisfactory & $44.8 \%$ & $44.57 \%$ & $40.62 \%$ \\
$(1)+(2)$ & $94.57 \%$ & $99.30 \%$ & $99.55 \%$ \\
Not satisfactory & $5.43 \%$ & $0.70 \%$ & $0.45 \%$ \\
\hline
\end{tabular}

Note. Data source: Special office of provincial government performance measurement.

\section{Jiangsu Practice Two: Features of Performance Measurement of City \& County Governments Launched by the Provincial Government}

In the first twenty years of 21 st century, the key stated mission of the Chinese government is to build a "comprehensive well-off society". All resources were mobilized to promote the unprecedented cause in China. As an advanced province in China, Jiangsu was devoted to taking the lead of accomplishing this great task. In 2003, Jiangsu Provincial Government initially formulated a set of indicators to guide as well as measure the progress of "well-off society construction", which comprehensively covers economic, social, environmental, and human development.

It is commonly recognized that modernization in China is a government-conducted process. Accordingly, to promote "well-off society construction" becomes the first priority of government administrative agenda. To a great extent, the progress of "well-off society construction" is equivalent to performance of government. Since considerable development gaps existed in different cities and counties of Jiangsu, the provincial government 
realized that it should be prudent to appraise the annual progress of "well-off society construction" in 13 city governments and 52 county governments. Obviously, to formulate a set of indicators was an essential step in implementing the project. Moreover, collecting accurate data was critically important. Without a doubt, the provincial government believes that all the municipal and county governments will be highly responsible for pushing forward "well-off society construction". The problem is that lower governments tend to overstate achievements of their own. For this reason, other approaches must be introduced to avoid possible flaws in the process of indicator system designing and monitoring. In this regard, related agencies should take necessary responsibilities to collect particular data and consistently keep track of performance information. On the one hand, the performance measurement program will guide lower level governments to make great efforts in accomplishing the designated tasks, with special emphasis on reaching the required standards. On the other hand, the program demands that related agencies get extensively involved in the process of performance measurement.

To evaluate the performance of the 13 prefecture-level cities and 52 county governments, some essential steps were undertaken as follows:

(1) Formulating a well-designed indicator system. In order to explicitly demonstrate the great mission, namely "well-off society construction" in Jiangsu, an ad hoc panel was set up to figure out indicators. They suggested an indicator scheme after working together with the Provincial Research Department, studying successful examples, and investigating the empirical evidence. Four primary indicators which reasonably reflect key elements of "well-off society construction" in Jiangsu were widely accepted by different levels of governments. They stand for "economic development", "people's living condition", "social development", and "environmental construction". Under the four primary indicators, 18 secondary indicators and 25 tertiary indicators were designed (see Table 7). The indicator system properly illustrated basic requirements and people's desire for a "well-off society construction". Considering annual development level of Jiangsu, the designers suggested 2002 as the starting point, and set 2010 data as the benchmark. In other words, they presupposed that Jiangsu Province as a whole would realize the great mission of a "well-off society" in 2010. Then, the ad hoc panel conceived "well-off society" as a set of standard data which would manifest the development level of the four primary indicators;

Table 7

Indicator System and Annual Development Performance in Jiangsu Province (2003-2009)

\begin{tabular}{|c|c|c|c|c|c|c|c|c|c|c|}
\hline Indicators & Unit & $\begin{array}{l}\text { Starting } \\
\text { point data } \\
(2002) \\
\end{array}$ & $\begin{array}{l}\text { Standard } \\
\text { data in } 2010 \\
(\mathrm{SD})\end{array}$ & $\begin{array}{l}\text { Accomplished } \\
\text { data in } 2003 \\
(2003 \text { AD) }\end{array}$ & $\begin{array}{l}2004 \\
\mathrm{AD}\end{array}$ & $\begin{array}{l}2005 \\
\mathrm{AD}\end{array}$ & $\begin{array}{l}2006 \\
\mathrm{AD}\end{array}$ & $\begin{array}{l}2007 \\
\mathrm{AD}\end{array}$ & $\begin{array}{l}2008 \\
\mathrm{AD}\end{array}$ & $\begin{array}{l}2009 \\
\mathrm{AD}\end{array}$ \\
\hline \multicolumn{11}{|l|}{ (1) Economic development } \\
\hline (1) GDP per capita & RMB & 14,397 & $\geq 24,000$ & 16,796 & 20,852 & 24,515 & 528,685 & 33,689 & 39,622 & 44,232 \\
\hline $\begin{array}{l}\text { (2) Percentage of the secondary } \\
\text { and tertiary industry }\end{array}$ & $\%$ & 89.4 & $\geq 92$ & 91.1 & 91.5 & 92.4 & 92.8 & 93.2 & 93.1 & 93.5 \\
\hline (3) Urbanization ratio & $\%$ & 44.7 & 55 & 46.8 & 48.2 & 50.5 & 51.9 & 53.2 & 54.3 & 55.6 \\
\hline (4) Unemployment rate & $\%$ & 4.5 & $<5$ & 4.1 & 3.9 & 3.6 & 3.4 & 3.19 & 3.3 & 3.2 \\
\hline \multicolumn{11}{|l|}{ (2) People's living condition } \\
\hline \multicolumn{11}{|l|}{ (1) Resident income } \\
\hline $\begin{array}{l}\text { (a) Disposable income per capita } \\
\text { of residents in urban areas }\end{array}$ & RMB & 8,178 & $\geq 16,000$ & $9,262.5$ & 10,482 & 12,319 & 14,084 & 16,378 & 18,680 & 20,552 \\
\hline $\begin{array}{l}\text { (b) The income per capita of } \\
\text { residents in rural areas }\end{array}$ & RMB & 3,996 & $\geq 8,000$ & $4,239.0$ & 4,754 & 5,276 & 5,813 & 6,561 & 7,357 & 8,004 \\
\hline (2) People's housing & & & & & & & & & & \\
\hline
\end{tabular}


Table 7 continued

\begin{tabular}{|c|c|c|c|c|c|c|c|c|c|c|}
\hline \\
\hline $\begin{array}{l}\text { (a) The per capita construction } \\
\text { size of housing in urban areas } \\
\text { (b) The per capita size of brick }\end{array}$ & $\mathrm{M}^{2}$ & 26.47 & 30 & 26.86 & 27.2 & 30.2 & 31.6 & 32.7 & 32.4 & 32.9 \\
\hline $\begin{array}{l}\text { and cement (permanent not } \\
\text { temporary) housing in rural areas }\end{array}$ & $\mathrm{M}^{2}$ & 34.2 & 40 & 35.46 & 35.8 & 38.2 & 40.7 & 42.7 & 43.8 & 45.1 \\
\hline \multicolumn{11}{|l|}{ (3) Transportation } \\
\hline \multicolumn{11}{|l|}{ (a) The percentage of permanent } \\
\hline $\begin{array}{l}\text { road connecting with } \\
\text { administrative village }\end{array}$ & $\%$ & 119 villages \& 1 town not & 100 & 100.0 & 100.0 & 100.0 & 100.0 & 100.0 & 100.0 & 100.0 \\
\hline $\begin{array}{l}\text { (b) Road scale per capital in } \\
\text { urban areas }\end{array}$ & $\mathrm{M}^{2}$ & 11.7 & 12 & 13.51 & 14.5 & 15.4 & 18.8 & 18.2 & 19.6 & 20.2 \\
\hline \multicolumn{11}{|l|}{ (4) Informationization rate } \\
\hline $\begin{array}{l}\text { (a) Number of telephone } \\
\text { installation per } 100 \text { families }\end{array}$ & & 120 & 200 & 154.98 & 177.1 & 209.8 & 226.0 & 244.5 & 253.9 & 264.2 \\
\hline $\begin{array}{l}\text { (b) Number of computer per } \\
100 \text { families }\end{array}$ & & 10 & 40 & 14.16 & 16.5 & 24.8 & 29.2 & 34.0 & 40.0 & 45.6 \\
\hline $\begin{array}{l}\text { (5) The percentage of expenditure } \\
\text { of education, entertainment, etc. } \\
\text { in the whole expenditure }\end{array}$ & $\%$ & 13.7 & 18 & 14.24 & 13.5 & 14.2 & 14.3 & 14.7 & 14.3 & 14.6 \\
\hline (6) Engel coefficient & $\%$ & 40.2 & $<40$ & 39.91 & 42.2 & 40.6 & 38.8 & 39.0 & 39.5 & 37.6 \\
\hline \multicolumn{11}{|l|}{ (3) Social development } \\
\hline (1) R\&D expenditure out of GDP & $\%$ & 1 & $\geq 1.5$ & 1.17 & 1.30 & 1.48 & 1.53 & 1.70 & 1.80 & 2.00 \\
\hline $\begin{array}{l}\text { (2) Gross enrollment rate at the } \\
\text { high school level }\end{array}$ & $\%$ & & $\geq 90$ & 60.0 & 66.3 & 71.0 & 76.7 & 85.7 & 90.0 & 95.0 \\
\hline $\begin{array}{l}\text { (3) Rate of health service } \\
\text { system improvement }\end{array}$ & $\%$ & 57 & $\geq 90$ & 67.54 & 77.1 & 85.6 & 90.2 & 95.9 & 99.7 & 99.8 \\
\hline \multicolumn{11}{|l|}{ (4) Social security } \\
\hline $\begin{array}{l}\text { (a) Three basic security } \\
\text { guarantee in urban areas }\end{array}$ & $\%$ & 91 & $\geq 95$ & 95.84 & 92.1 & 95.0 & 96.0 & 97.0 & 97.2 & 97.5 \\
\hline $\begin{array}{l}\text { (b) New rural cooperative } \\
\text { medical care }\end{array}$ & $\%$ & 35.4 & $\geq 85$ & 34.20 & 71.9 & 85.5 & 93.2 & 95.0 & 98.9 & 99.5 \\
\hline \multicolumn{11}{|l|}{$\begin{array}{l}\text { (6) Autonomy by law in urban } \\
\text { and rural areas }\end{array}$} \\
\hline (a) Urban communities & $\%$ & 80.0 & 90 & 90.0 & 91.2 & 93.4 & 95.4 & 96.3 & 96.7 & 97.6 \\
\hline (b) Rural village & $\%$ & 85 & 95 & 94.00 & 95.3 & 96.3 & 97.1 & 97.5 & 98.1 & 98.8 \\
\hline
\end{tabular}

(4) Environmental construction

(1) Country green

(a) Green-plants coverage in urban areas

\begin{tabular}{ll}
$\%$ & 35.3 \\
$\%$ & 10.6 \\
& 63.4 \\
\hline
\end{tabular}

$\begin{array}{llllllll}40 & 35.35 & 37.5 & 39.0 & 41.7 & 42.6 & 42.1 & 41,3\end{array}$

(b) Forest coverage $\quad \% \quad 10.6$

(2) Environmental quality

comprehensive index

$\begin{array}{llllllll}20 & 11.36 & 13.9 & 14.8 & 15.8 & 16.9 & 18.1 & 19.2\end{array}$

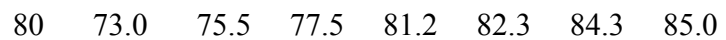

Notes. AD is the abbreviation of accomplished data; SD is the abbreviation of standard data; data source: Statistic annual reporting of Jiangsu Provincial Statistic Bureau (since 2002 to 2009).

(2) Assigning proper responsibilities to related provincial government agencies. On the basis of individual special responsibility, nearly 10 government agencies were involved in the process of performance measurement. They were mainly in charge of collecting exact data and keeping track of city and county governments' annual performance. In particular, the Provincial Department of Justice was responsible for collecting the data of "satisfaction rate of public security"; the Provincial Forestry Bureau was responsible for collecting the data of "forest coverage"; the Provincial Department of Health was responsible for collecting "coverage of health services system" and "coverage of new rural cooperative medical care"; the Provincial 
Civil Administration was responsible for collecting "number of autonomy by law in urban communities" and "number of autonomy by law in rural villages"; the Provincial Department of Construction was responsible for collecting "green plants coverage in urban areas" and "road scale per capital in urban areas"; the Provincial Transportation Department was responsible for collecting "the percentage of permanent roads connecting with each administrative village"; the Provincial Environment Department was responsible for collecting "environmental quality comprehensive index". The task of collecting other indicators was assigned to the Provincial Statistic Bureau. The Provincial Statistic Bureau was further responsible for examining all data to ascertain their accuracy and credibility;

(3) Comparing current data with the benchmark. All the prefecture-level city and county governments would pay much more attention to such a comparison, simply because it was closely related to progress, either for the reputation of the city/county as a whole or for any promotion opportunities of individual leaders. If one city/county accomplishes the standard value earlier than others, it will be upheld as a good example for the others to follow. The earlier it achieves the standard value, the better the interests of the residents as well as the leaders will be satisfied. Normally, it is a very effective incentive and encouragement. For example, Suzhou is the most advanced city in Jiangsu, thereby high expectations are put on the municipal government. Fortunately, by the end of 2004, 14 out of all 25 indicators had reached the standard values; by the end of 2005, 22 out of 25 indicators had reached the benchmark. Eventually, by the end of 2006, all the indicators had reached the desired goal. Likewise, Kunshan County had reached all the benchmark standards by the end of 2005, which was the first ranking in the line of having fulfilled "well-off society construction" task;

(4) Publishing annual monitoring report and giving comments. Starting from 2005, the provincial government entrusted publishing annual monitoring reports to the Provincial Statistic Bureau. The annual monitoring report reflected the major performance of municipal governments (and also county governments directly subordinate to a particular municipal government) in a particular year. In an annual report, on the basis of overall performance of 13 cities, the authoritative agency will publish the real data of each indicator, pointing out the progress or lack thereof, analyzing objective reasons and giving comments. As for individual cities and counties, the agency will state how many indicators have and have not been accomplished (see Tables 8 and 9, taking two cities like Nanjing, Changzhou, two counties like Yixing, Haimeng as examples). Thus, all the city and county governments will be able to objectively compare their performance, both with other city and county governments, and with their own trend of historical performances across time;

Table 8

Indicator System and Annual Development Performance in Nanjing and Changzhou (Two Cities)

\begin{tabular}{|c|c|c|c|c|c|c|}
\hline Indicators & Unit & $\begin{array}{l}\text { Standard data } \\
\text { in } 2010(\mathrm{SD})\end{array}$ & $\begin{array}{l}\text { Accomplished data } \\
\text { in Nanjing in } 2004 \\
\text { (2004 AD) }\end{array}$ & $\begin{array}{l}2005 \\
\text { AD in } \\
\text { Nanjing }\end{array}$ & $\begin{array}{l}\text { Accomplished data } \\
\text { in Changzhou in } \\
2005 \\
(2005 \text { AD) }\end{array}$ & $\begin{array}{l}2006 \\
\text { AD in } \\
\text { Changzhou }\end{array}$ \\
\hline \multicolumn{7}{|l|}{ (1) Economic development } \\
\hline (1) GDP per capita & RMB & $\geq 24,000$ & 33,050 & Arrived & 31,998 & 37,210 \\
\hline $\begin{array}{l}\text { (2) Percentage of the secondary } \\
\text { and tertiary industry }\end{array}$ & $\%$ & $\geq 92$ & 96.3 & Arrived & 95.7 & 96.2 \\
\hline (3) Urbanization ratio & $\%$ & 55 & 75.3 & Arrived & 60.3 & 60.5 \\
\hline (4) Unemployment rate & $\%$ & $<5$ & 4.03 & Arrived & 3.5 & 3.4 \\
\hline \multicolumn{7}{|l|}{ (2) People's living condition } \\
\hline (1) Resident income & & & & & & \\
\hline
\end{tabular}


Table 8 continued

\begin{tabular}{|c|c|c|c|c|c|c|}
\hline $\begin{array}{l}\text { (a) Disposable income per } \\
\text { capita of residents in urban areas }\end{array}$ & RMB & $\geq 16,000$ & 11,602 & Not & 14,589 & 16,150 \\
\hline $\begin{array}{l}\text { (b) The income per capita of } \\
\text { residents in rural areas }\end{array}$ & RMB & $\geq 8,000$ & 5,533 & Not & 7,002 & 8,001 \\
\hline \multicolumn{7}{|l|}{ (2) People's housing } \\
\hline $\begin{array}{l}\text { (a) The per capita construction } \\
\text { size of housing in urban areas }\end{array}$ & $\mathrm{M}^{2}$ & 30 & 21.6 & Arrived & 28.5 & 30 \\
\hline $\begin{array}{l}\text { (b) The per capita size of brick } \\
\text { and cement (permanent not } \\
\text { temporary) housing in rural areas }\end{array}$ & $\mathrm{M}^{2}$ & 40 & 37.57 & Arrived & 55.7 & 57.2 \\
\hline \multicolumn{7}{|l|}{ (3) Transportation } \\
\hline $\begin{array}{l}\text { (a) The percentage of permanent } \\
\text { road connecting with } \\
\text { administrative village }\end{array}$ & $\%$ & 100 & 100.0 & 100.0 & 100.0 & 100.0 \\
\hline $\begin{array}{l}\text { (b) Road scale per capital in } \\
\text { urban areas }\end{array}$ & $M^{2}$ & 12 & 13.0 & Arrived & 17.9 & 18.0 \\
\hline \multicolumn{7}{|l|}{ (4) Informationization rate } \\
\hline $\begin{array}{l}\text { (a) Number of telephone } \\
\text { installation per } 100 \text { families }\end{array}$ & & 200 & 204.8 & 234.9 & 250.8 & 262.1 \\
\hline $\begin{array}{l}\text { (b) Number of computers per } \\
100 \text { families }\end{array}$ & & 40 & 35.3 & 50.0 & 36.1 & 41.5 \\
\hline $\begin{array}{l}\text { (5) The percentage of expenditure } \\
\text { of education, entertainment, etc. } \\
\text { in the whole expenditure }\end{array}$ & $\%$ & 18 & 14.6 & 12.9 & 13.4 & 13.4 \\
\hline (6) Engel coefficient & $\%$ & $<40$ & 43.1 & 36.2 & 37.4 & 36.5 \\
\hline \multicolumn{7}{|l|}{ (3) Social development } \\
\hline (1) R\&D expenditure out of GDP & $\%$ & $\geq 1.5$ & 3.19 & Arrived & 1.63 & 1.64 \\
\hline $\begin{array}{l}\text { (2) Gross enrollment rate at the } \\
\text { high school level }\end{array}$ & $\%$ & $\geq 90$ & 99.6 & Arrived & 100.0 & 100.0 \\
\hline $\begin{array}{l}\text { (3) Rate of health service } \\
\text { system improvement }\end{array}$ & $\%$ & $\geq 90$ & 73.9 & 80.3 & 96.2 & 100.0 \\
\hline \multicolumn{7}{|l|}{ (4) Social security } \\
\hline $\begin{array}{l}\text { (a) Three basic security } \\
\text { guarantee in urban areas }\end{array}$ & $\%$ & $\geq 95$ & 91.0 & 95.8 & 94.1 & 96.7 \\
\hline $\begin{array}{l}\text { (b) New rural cooperative } \\
\text { medical care }\end{array}$ & $\%$ & $\geq 85$ & 76.0 & 90.9 & 93.4 & 97.8 \\
\hline $\begin{array}{l}\text { (5) Satisfaction rate of public } \\
\text { security } \\
\text { (6) Autonomy by law in urban } \\
\text { and rural areas }\end{array}$ & $\%$ & 90 & 94.8 & Arrived & 96.7 & 97.3 \\
\hline (a) Urban communities & $\%$ & 90 & 91.0 & Arrived & 98.0 & 99.0 \\
\hline (b) Rural village & $\%$ & 95 & 96.0 & Arrived & 98.0 & 99.0 \\
\hline
\end{tabular}

\section{(4) Environmental construction}

(1) Country green urban areas

(b) Forest coverage $\% \quad 40$

44.5

Arrived

40.6

(2) Environmental quality

$\% \quad 20$

20.0

Arrived

14.7

comprehensive index

71.2

66.4

80.3

Note. Data source: Statistic annual reporting of Jiangsu Provincial Statistic Bureau; statistic annual reporting of Nanjing and Changzhou Municipal Statistic Bureau.

(5) Modifying indicators and methods in accordance with the public feedback. In the process of performance measurement, the provincial government paid close attention to public opinion. There were two typical examples involved. One was to differentiate some indicators among different levels of governments. For 
example, at the provincial and municipal level, the benchmark value of R\&D expenditure out of GDP was set at $1.5 \%$, but it did not fit well with the needs at the county level. Therefore, in 2006, the benchmark value of the indicator was adjusted from $1.5 \%$ to $1.0 \%$ so as to fit the real situation of counties. The other was to ensure consistency between what the indicators indicated and how people perceived things. Deviation between two aspects is unavoidable but distinctive divergence is not permitted. Also in 2006, the provincial government introduced a third-party organization to conduct an opinion poll in some counties. By doing so, it could potentially avoid possible flaws as well as make up for possible shortcomings of the indicator system. Theoretically speaking, if the recognition of opinion polls is above $60 \%$, it will provide substantial weight for the results induced from the indicator system. Fortunately, the evaluation deviation by two methods was not so significant, that is, all the opinion polls conducted in nine counties demonstrated that most people basically accepted the judgment officially released by the provincial government (see Table 10). It actually proved the credibility of the indicator system as well.

Table 9

Indicator System and Annual Development Performance in Yixing and Haimeng (Two Counties)

\begin{tabular}{|c|c|c|c|c|c|c|}
\hline Indicators & Unit & $\begin{array}{l}\text { Standard data } \\
\text { in } 2010 \text { (SD) }\end{array}$ & $\begin{array}{l}\text { Accomplished data } \\
\text { in Yixing in } 2005 \\
(2005 \text { AD) }\end{array}$ & $\begin{array}{l}2006 \\
\text { AD in } \\
\text { Yixing }\end{array}$ & $\begin{array}{l}\text { Accomplished data } \\
\text { in Haimeng in } \\
2005 \\
(2005 \text { AD) }\end{array}$ & $\begin{array}{l}2006 \\
\text { AD in } \\
\text { Haimeng }\end{array}$ \\
\hline \multicolumn{7}{|l|}{ (1) Economic development } \\
\hline (1) GDP per capita & RMB & $\geq 24,000$ & 31,820 & 35,900 & 20,928 & 22,538 \\
\hline $\begin{array}{l}\text { (2) Percentage of the secondary } \\
\text { and tertiary industry }\end{array}$ & $\%$ & $\geq 92$ & 95.5 & 96.9 & 89.3 & 92.86 \\
\hline (3) Urbanization ratio & $\%$ & 55 & 55 & 55.25 & 42.82 & 42.82 \\
\hline (4) Unemployment rate & $\%$ & $<5$ & 2.61 & 2.9 & 2.8 & 2.48 \\
\hline \multicolumn{7}{|l|}{ (2) People's living condition } \\
\hline \multicolumn{7}{|l|}{ (1) Resident income } \\
\hline $\begin{array}{l}\text { (a) Disposable income per } \\
\text { capita of residents in urban areas }\end{array}$ & RMB & $\geq 16,000$ & 13,832 & 16,776 & 12,203 & 14,434 \\
\hline $\begin{array}{l}\text { (b) The income per capita of } \\
\text { residents in rural areas }\end{array}$ & RMB & $\geq 8,000$ & 7,010 & 8,017 & 6,558 & 7,652 \\
\hline \multicolumn{7}{|l|}{ (2) People's housing } \\
\hline $\begin{array}{l}\text { (a) The per capita construction } \\
\text { size of housing in urban areas }\end{array}$ & $\mathrm{M}^{2}$ & 30 & 35.9 & 35.9 & 34.80 & 35.05 \\
\hline $\begin{array}{l}\text { (b) The per capita size of brick } \\
\text { and cement (permanent not } \\
\text { temporary) housing in rural areas }\end{array}$ & $\mathrm{M}^{2}$ & 40 & 44.5 & 44.7 & 45.9 & 46.1 \\
\hline \multicolumn{7}{|l|}{ (3) Transportation } \\
\hline $\begin{array}{l}\text { (a) The percentage of } \\
\text { permanent road connecting } \\
\text { with administrative village }\end{array}$ & $\%$ & 100 & 100.0 & 100.0 & 100.0 & 100.0 \\
\hline $\begin{array}{l}\text { (b) Road scale per capital in } \\
\text { urban areas }\end{array}$ & $\mathrm{M}^{2}$ & 12 & 20.87 & 20.87 & 14.95 & 14.95 \\
\hline \multicolumn{7}{|l|}{ (4) Informationization rate } \\
\hline $\begin{array}{l}\text { (a) Number of telephone } \\
\text { installation per } 100 \text { families }\end{array}$ & & 200 & 247.6 & 262 & 228 & 232 \\
\hline $\begin{array}{l}\text { (b) Number of computer per } \\
100 \text { families }\end{array}$ & & 40 & 29.1 & 34 & 17 & 18.8 \\
\hline $\begin{array}{l}\text { (5) The percentage of expenditure } \\
\text { of education, entertainment, etc. } \\
\text { in the whole expenditure }\end{array}$ & $\%$ & 18 & 12.5 & 12.3 & 10.6 & 10.1 \\
\hline (6) Engel coefficient & $\%$ & $<40$ & 39.2 & 38.9 & 40.4 & 39.7 \\
\hline
\end{tabular}


Table 9 continued

\begin{tabular}{|c|c|c|c|c|c|c|}
\hline \multicolumn{7}{|l|}{ (3) Social development } \\
\hline $\begin{array}{l}\text { (1) R\&D expenditure out of } \\
\text { GDP }\end{array}$ & $\%$ & $\geq 1.5$ & 1.5 & 1.7 & 0.85 & 0.86 \\
\hline $\begin{array}{l}\text { (2) Gross enrollment rate at the } \\
\text { high school level }\end{array}$ & $\%$ & $\geq 90$ & 93.5 & 93.8 & 90.3 & 95.02 \\
\hline $\begin{array}{l}\text { (3) Rate of health service } \\
\text { system improvement } \\
\text { (4) Social security }\end{array}$ & $\%$ & $\geq 90$ & 91 & 92 & 96 & 97 \\
\hline $\begin{array}{l}\text { (a) Three basic security } \\
\text { guarantee in urban areas }\end{array}$ & $\%$ & $\geq 95$ & 98 & 98 & 99.63 & 99.68 \\
\hline $\begin{array}{l}\text { (b) New rural cooperative } \\
\text { medical care }\end{array}$ & $\%$ & $\geq 85$ & 96.2 & 98.1 & 91.50 & 88.33 \\
\hline $\begin{array}{l}\text { (5) Satisfaction rate of public } \\
\text { security } \\
\text { (6) Autonomy by law in urban } \\
\text { and rural areas }\end{array}$ & $\%$ & 90 & 96 & 97 & 100 & 100 \\
\hline (a) Urban communities & $\%$ & 90 & 99 & 99 & 100 & 100 \\
\hline (b) Rural village & $\%$ & 95 & 97.5 & 98 & 100 & 100 \\
\hline \multicolumn{7}{|l|}{ (4) Environmental construction } \\
\hline \multicolumn{7}{|l|}{ (1) Country green } \\
\hline $\begin{array}{l}\text { (a) Green-plants coverage in } \\
\text { urban areas }\end{array}$ & $\%$ & 40 & 42.28 & 42.3 & 28.26 & 28.52 \\
\hline (b) Forest coverage & $\%$ & 20 & 28.6 & 28.6 & 16.3 & 17.49 \\
\hline $\begin{array}{l}\text { (2) Environmental quality } \\
\text { comprehensive index }\end{array}$ & & 80 & 88.8 & 70.3 & 96 & 96 \\
\hline
\end{tabular}

Note. Data source: Statistic annual reporting of Jiangsu Provincial Statistic Bureau; statistic annual reporting of Yixing and Haimeng County Statistic Bureau.

Table 10

Opinion Polls on the Public Recognition in Nine Counties in 2006

\begin{tabular}{|c|c|c|c|c|c|c|c|c|c|}
\hline & 1 & 2 & 3 & 4 & 5 & 6 & 7 & 8 & 9 \\
\hline County & Kunshang & Zhangjiagang & Changshu & Jiangying & Wujiang & Taicang & Yixin & Yangzhong & Wujin \\
\hline Recognition & $73.2 \%$ & $73.0 \%$ & $72.8 \%$ & $72.0 \%$ & $68.4 \%$ & $60.6 \%$ & $73.0 \%$ & $72.2 \%$ & $66.8 \%$ \\
\hline
\end{tabular}

Note. Data source: Statistic annual reporting of Jiangsu Provincial Statistic Bureau 2007.

\section{Summary and Analysis}

\section{Jiangsu's Practice Is Consistent With Normal Standard of Government Performance Measurement}

Based on the practice of Jiangsu Provincial Government performance measurement, the authors have the following observations:

(1) Two kinds of performance measurements are favorably regarded as normal government performance measurements. Although the performance measurements of "well-off society construction" and "government employees' work discipline" are separately deployed, each also has its particular concentration. They can be generally viewed as normal government performance measurements. Both actions are based on government accountability, committed to achieving desired outcomes, and focused on evaluating the government agencies or employees. The special questionnaire survey also proved that two actions are highly related to government performance in general (see Table 11 and Table 12);

(2) Out of 361 valid questionnaires, 297 people positively think the evaluation of work discipline is related to normal government performance measurement. Similarly, out of 361 valid questionnaires, 324 people 
positively think the evaluation of "well-off society construction" is related to normal government performance measurement. Interestingly, for the officials from Jiangsu provincial government agencies, $100 \%$ positively think both are related in some way. In contrast, only $73.9 \%$ officials from municipal and county governments think the evaluation of administration discipline and work ethic can be viewed as a sort of government performance measurement; only $70.1 \%$ officials from the same agencies think the evaluation of "well-off society construction" can be viewed as a sort of government performance measurement. Nevertheless, most people think positively about the relationship between the two particular evaluations and normal government performance measurement.

Table 11

The Attitude Towards the Relationship Between Administration Discipline Evaluation and Normal Government Performance Measurement

\begin{tabular}{|c|c|c|c|c|c|c|}
\hline & $\begin{array}{l}\text { Officials from } \\
\text { the provincial } \\
\text { government } \\
(135)\end{array}$ & $\begin{array}{l}\text { Officials from } \\
\text { municipal and county } \\
\text { governments }(77)\end{array}$ & $\begin{array}{l}\text { Officials from the } \\
\text { governments below } \\
\text { county level }(50)\end{array}$ & $\begin{array}{l}\text { University } \\
\text { students (50) }\end{array}$ & $\begin{array}{l}\text { Ordinary } \\
\text { people (49) }\end{array}$ & $\begin{array}{l}\text { A certain of } \\
\text { attitude in } \\
\text { total }\end{array}$ \\
\hline Very closely related & 78 & 12 & 11 & 7 & 3 & $111 / 361$ \\
\hline Closely related & 40 & 20 & 17 & 22 & 27 & $126 / 361$ \\
\hline Related & 17 & 20 & 15 & 3 & 8 & $60 / 361$ \\
\hline Not related & 0 & 0 & 0 & 0 & 2 & $2 / 361$ \\
\hline Not related at all & 0 & 1 & 0 & 0 & 1 & $2 / 361$ \\
\hline Results not demonstrated & 0 & 24 & 7 & 1 & 8 & $40 / 361$ \\
\hline Positive attitude in total & $135 / 135$ & $52 / 77$ & $43 / 50$ & $42 / 50$ & $38 / 49$ & $297 / 361$ \\
\hline
\end{tabular}

Table 12

The Attitude Towards the Relationship Between "Well-off Society Construction" Evaluation and Normal Government Performance Measurement

\begin{tabular}{|c|c|c|c|c|c|c|}
\hline & $\begin{array}{l}\text { Officials } \\
\text { from the } \\
\text { provincial } \\
\text { government } \\
(135)\end{array}$ & $\begin{array}{l}\text { Officials from } \\
\text { municipal and county } \\
\text { governments }(77)\end{array}$ & $\begin{array}{l}\text { Officials from the } \\
\text { governments below } \\
\text { county level (50) }\end{array}$ & $\begin{array}{l}\text { University } \\
\text { students (50) }\end{array}$ & $\begin{array}{l}\text { Ordinary } \\
\text { people (49) }\end{array}$ & $\begin{array}{l}\text { A certain of } \\
\text { attitude in } \\
\text { total }\end{array}$ \\
\hline Very closely related & 74 & 13 & 10 & 5 & 4 & $106 / 361$ \\
\hline Closely related & 45 & 32 & 21 & 23 & 25 & $136 / 361$ \\
\hline Related & 16 & 20 & 15 & 19 & 12 & $82 / 361$ \\
\hline Not related & 0 & 0 & 0 & 1 & 2 & $3 / 361$ \\
\hline Not related at all & 0 & 1 & 0 & 1 & 1 & $3 / 361$ \\
\hline Results not demonstrated & 0 & 11 & 4 & 1 & 5 & $22 / 361$ \\
\hline Positive attitude in total & $135 / 135$ & $55 / 77$ & $46 / 50$ & $47 / 50$ & $41 / 49$ & $324 / 361$ \\
\hline
\end{tabular}

\section{Jiangsu's Particulars in Government Performance Measurement}

(1) The government performance measurement in Jiangsu represents a results-orientation. It is in accordance with the current trend of performance measurement in the world. To achieve good performance in "three changes" stands for a particular result of provincial government agencies. Further, the mission of "well-off society construction" stands for the desire or expectation of different levels of governments as well as the people. In other words, by measuring the results, the provincial government could successfully lead lower governments as well as provincial government agencies to achieve desired outputs, while simultaneously paying close attention to further impacts on the society. 
(2) Target management is a useful tool for Jiangsu Provincial Government to promote performance measurement. Indeed, "establishing targets (or at least projected values) for each outcome indicator for the coming performance period is a highly useful management tool" (Hatry, 2006). Jiangsu Provincial Government attaches much importance to target management in the whole process of performance measurement. It is especially exhibited in the process of measuring the overall development performance in city and county territories. The provincial government sets the "well-off society" as the common goal of Jiangsu. All the cities and counties are required to work towards the same target. What is more, the provincial government set 2010 as the benchmark year, and projected the development level in main fields, especially quantified key indicators in terms of the projection. On the basis of 2010 standard data, the provincial government as well as the city and county governments can compare annual achievements with the benchmark target at the end of a particular year. It automatically stimulates all levels of governments to make great efforts to reach annual goals without arguing, and ultimately reach the benchmark standards.

(3) Developing indicators is a critically essential process when Jiangsu Provincial Government carries out performance measurement. As Harry P. Hatry pointed out, "selecting the specific indicators to measure is a key part of developing a performance measurement system" (Hatry, 2006). Either in measuring the government employee's performance or administrative performance, Jiangsu Provincial Government pays close attention to selecting adequate indicators. Specific indicators can illustrate seemingly abstract concepts. In particular, in order to assess the annual progress of "well-off society construction", the provincial government qualifies "well-off society construction" as four major facets such as economic development, people's living condition, social development, and environmental construction. Roughly, the four facets can cover most constructions in regional development in terms of modernization progress. Under this indicator system, more breakouts are specified as 18 secondary indicators and 25 territory indicators. The provincial government also emphasized that the three key elements, namely "GDP per capital, income per capital, social security and environmental condition", can mostly stand for the level of "well-off society construction". Even if some minor indicators have not reached the standards, the provincial government still can give positive evaluation to "well-off society construction".

(4) The practice of Jiangsu Provincial Government measurement is tightly around government accountability and policy implementation. On the one hand, we can see accountability existing everywhere in government policies and actions in practice. Especially, all levels of government should fulfill their particular accountabilities to promote economic and social development so as to meet increasing needs of the people. On the other hand, the performance measurement is mainly for promoting implementation of provincial government policies.

(5) Although two types of measurements have their particular emphases, they converge on an integrated performance measurement pattern in Jiangsu. Normally, government performance measurement mainly focuses on two elements: One is the employee's performance, and the other is administrative performance (Shang, 2009b). The two aspects are based on the same precondition: accountability.

(6) The performance measurement in Jiangsu is a typically leader-conducted action, which represents stronger powers of provincial government over the lower governments. Admittedly, the federal government or state governments in America also play very important roles in the process of performance measurement. However, in the relatively decentralized United States, government must coordinate with other forces, especially the force of law or a third party, in order to function effectively. 


\section{Weaknesses in Jiangsu Government Performance Measurement}

In spite of the above positive points, the authors observe some shortcomings of government performance measurement in Jiangsu as follows: (1) The practice in Jiangsu ignores the objective difference of accountabilities existing in different agencies, simply evaluating different types of agencies by ranking based on their accomplishments and performance; (2) Indicator logic is not so consistent in the whole process of performance measurement. In general, the usual logic of performance measurement is input - output - outcome, accordingly the indicator logic usually follows it and specifies it; (3) The specific meanings of some major indicators are ambiguous; (4) For the indicators used in practice, no adequate calculating weights are assigned to them. On the contrary, some weights are assigned to the evaluators. After all, it is not a normal way to measure performance; (5) In the whole process of performance measurement, self-evaluation plays a very important role; (6) Criteria mainly come from the expectation of the provincial government. Evaluation mainly comes from the comparison of real performance against expectation of the government; (7) The final performance results are mainly associated with the promotion of some important officials rather than the budgeting of a particular level of government or a government agency; and (8) Although the public can get some chances to participate in the process of performance measurement, they only have limited influence on the final judgment (see Table 13).

Table 13

Opinions and Attitudes to the Government Performance Measurement in Jiangsu

\begin{tabular}{|c|c|c|c|c|c|c|c|}
\hline & 1 & 2 & 3 & 4 & 5 & 6 & $\begin{array}{l}\text { Positively } \\
\text { agree (\%) }\end{array}$ \\
\hline About government performance measurement's basic goal in theory & 323 & 25 & 11 & 0 & 0 & 2 & $359 / 361$ \\
\hline About government performance measurement's significance and real effect in practice & 65 & 179 & 103 & 6 & 5 & 3 & $347 / 361$ \\
\hline About whether achieving the desired outcomes of evaluating work discipline or not & 96 & 171 & 87 & 0 & 0 & 6 & $355 / 361$ \\
\hline $\begin{array}{l}\text { About whether achieving the desired outcomes of evaluating "well-off society } \\
\text { construction" performance or not }\end{array}$ & 94 & 179 & 78 & 2 & 3 & 5 & $351 / 361$ \\
\hline About the public participation in evaluating work discipline & 12 & 113 & 123 & 84 & 10 & 19 & $248 / 361$ \\
\hline About the public participation in evaluating "well-off society construction" & 32 & 95 & 101 & 80 & 19 & 34 & $228 / 361$ \\
\hline About the public satisfaction of evaluating work discipline & 2 & 117 & 142 & 26 & 27 & 47 & $261 / 361$ \\
\hline About the public satisfaction of evaluating "well-off society construction" & 2 & 121 & 137 & 21 & 45 & 35 & $260 / 361$ \\
\hline About the public familiarity of indicators of evaluating work discipline & 0 & 120 & 113 & 40 & 42 & 46 & $233 / 361$ \\
\hline About the public familiarity of indicators of evaluating "well-off society construction" & 0 & 167 & 122 & 34 & 23 & 15 & $289 / 361$ \\
\hline About the frequency of government performance measurement in Jiangsu & 3 & 187 & 117 & 20 & 3 & 31 & $307 / 361$ \\
\hline
\end{tabular}

Notes. The attitude 1 stands for "strongly agree", 2 for "agree", 3 for "moderately agree", 4 for "don't agree", 5 for "don't agree at all", 6 for "results not demonstrated"; $1+2+3=$ positive agreement, $4+5=$ negative agreement

\section{Hypotheses Testing}

The following assumptions have been tested and confirmed by the authors' observation of Jiangsu practice of performance management in the past 10 years or so:

(1) Performance information is not comprehensive;

(2) Performance information is ambiguous;

(3) Performance information is subjective;

(4) Production of performance information does not guarantee use;

(5) Institutional affiliation and individual beliefs will affect selection, perception, and presentation of performance information;

(6) The context of dialogue will affect the ability to use performance information to develop solutions. 


\section{Recommendations}

From the analysis above, together with the special questionnaire survey and seminar from April to May in 2010, the authors would like to propose some recommendations:

\section{To Integrate Two Patterns on the Basis of Government Fundamental Accountability}

The two patterns of government performance measurement can be integrated into a unified project according to the basic accountability of government. Government agencies and employees are often confused with the two methods of evaluation. Under existing policy system of government performance measurement in Jiangsu, two types of evaluation, different organizers, processes, criteria, indicators, even results are actually unavoidable in reality. The simplest way is to adjust the two patterns on the basis of same values and policy of performance measurement. While the two patterns are based on the same macro-accountability, they both diverge in the process of operation. Therefore, under the precondition of government fundamental accountability, Jiangsu Province should bring diverged evaluation criteria, separated indicator systems, different evaluators, diverse objects to be evaluated, etc. into a consistent system. In this new unified framework, Jiangsu Province would rethink the government performance measurement action.

\section{To Enact Relevant Laws of Performance Measurement}

It is wise to make a provincial law to regulate all the elements, especially key factors of government performance measurement in Jiangsu. By doing so, the government performance measurement will be sustainable and acceptable at all levels of governments in Jiangsu in a long term.

\section{To Modify the Indicator System}

That is, to redesign a set of indicators which exactly represent the goal of performance measurement in Jiangsu. Indicator system will not only represent the core value, administrative idea of Jiangsu Provincial Government, but also highlight the management essence or execution orientation of all levels of government agencies. Accordingly, new indicators should be objective, simplified, achievable, consistent, and comparable. In the current context of Jiangsu practice, for evaluating the employee's performance, there are no available indicators to consult, either for the evaluator, namely the provincial government, or for the evaluated side, namely provincial government agencies. The target of "three changes" simply represents the desired goal or provincial government expectation, which must be specified into a particular indicator system. As for city and county governments' performance, although there is a set of indicator systems available for implementation, some indicators should be adjusted too. For example, a secondary-indicator called "environment quality comprehensive index" is very professional, and the meaning is not very clear. In practice, it should be broken out to be more detailed indicators. In terms of the current situation, it should include at least four elements: (1) days of having good air quality within one year; (2) the degree of reaching the standards for the water territorial area; (3) the degree of reaching the standards for the drinking water source area; and (4) the area coverage of reaching the standards for keeping environment from noise pollution. Therefore, it is important to add above-mentioned elements into the current indicator system so as to highlight the necessary factors which the public expect eagerly.

\section{To Highlight the Restriction of Government Budgeting}

In other words, to link performance with government budgeting. To control money is to control almost every source of administrative activity in modern society. In comparison, performance measurement in Jiangsu 
is usually associated with the promotion of government officials, but is not related to budget. In reality, budget restrictions always matter. It is almost universally effective worldwide. Taking USA as an example, OMB's PART is designed specifically and only for tightly linking federal programs' performance to budgeting. In July of 2002, the Director of OMB announced, "The program assessment effort presents an opportunity to inform and improve agency GPRA plans and reports, and establish a meaningful systematic link between GPRA and the budget process" [OMB (Office of Management and Budget), 2007].

\section{To Get Outsiders Involved}

In the authors' opinion, Jiangsu Provincial Government should boldly introduce more "outsiders", especially ordinary people to participate in the process of performance measurement. Multiple-evaluators engaging in the process of government performance measurement is becoming the mainstreamed trend worldwide (Shang, 2009a).

\section{Conclusions}

In this paper, the authors focus on studying the unique practice of Jiangsu Provincial Government measurement in the period of 2003-2009. Observing it seriously, either by comparing the practice with that of other regions in China or with normal practices in the US, or even the historical trend during recent years in the province, the authors find that Jiangsu's practice has been gradually moving towards the standard norm of government performance measurement. Although it is not completely in line with the basic logic of "inputs-activities - outputs - outcomes", it nevertheless indicates key elements, especially some important notions of government performance measurement such as "results-orientation", "goal-management", "customer-satisfaction", etc. It especially focuses on evaluating the government employees and lower-lever governments, which makes the measurement project be carried out easily and operationally. It also represents close connection between the evaluation and reward or punishment policy, which is likely to generate desirable results in government management. Obviously, in comparison, government performance measurement in USA does not show particular interest in evaluating accomplishments of individual officials or government employees. They simply pay attention to evaluating an agency's performance or a program's performance. Thus, focusing on evaluating individual officials' performance, such as administrative discipline, work ethic, work style, even employees' attitude, etc. can be recognized as a creation of Chinese characteristic of performance measurement.

It is true that performance measurement/management is in a premature stage in China in general and in Jiangsu in particular. However, even in an advanced democracy like USA, performance measurement/management can also hardly be said to be in a matured one, despite a much longer history of associated attempts and efforts. There are a lot of debates on the complexities of performance management (Moynihan, 2008). Radin has argued that performance management reforms can become a "one-size-fits-all" approach, failing to capture differences between programs (Radin, 2006). Indeed, commentator believes that:

Politics makes performance information irrelevant. Strong political preferences make performance information unnecessary. Relative to partisan goals, ideological biases, stakeholder pressure, and constituent needs, performance data are not especially influential. In addition, performance information does not help elected officials by making political decisions simpler-indeed, it is an additional layer of information to incorporate. (Moynihan, 2008, p. 11)

In 1999, after studying six state governments (Florida, Minnesota, North Carolina, Oregon, Texas, and 
Virginia), Aristigueta concluded that "Managing-for-results efforts remain an evolutionary process (and not absence of resistance) with identifiable characteristics... The efforts also remain a 'work in progress' and iterative by their very nature as each state plans modifications and improvements" (Aristigueta, 1999, p. 158). Yet, at the 2005 managing for results assessment, among 50 states in the USA, two got "D", eight got "C", and 15 got "C+", only five states earned "A-" grades (Moynihan, 2008, p. 13). This slow progress is indicative of the difficulty of performance improvement at the state level.

Using Moynihan's theory of the interactive dialogue model of performance information use to explain the Jiangsu case, the authors find the partial adoption of performance management doctrine, i.e., Jiangsu public managers have not been authorized necessary personnel and budgeting flexibility in their routine practice. The authors believe that symbolic benefits of adopting the performance measurement systems/indicators motivated the appointed and elected politicians as well as the lower level public managers in the province. These benefits may include a positive image in the media, often associated with an image of an innovative and creative reformer who attempts to improve efficiency, effectiveness, enhancing quality of lives and to a large extent "serving the people". It is also true that Jiangsu's practice of performance management in the past 10 years or so confirms Moynihan's hypotheses such as performance information that is not comprehensive, ambiguous, subjective, etc.

In the authors' case, Jiangsu Provincial Government performance measurement is neither a perfect example nor a cohesive system. After all, some practices and methods are inevitably far from perfect. It needs improvement in several ways, including standardizing major aspects of government performance, redesigning primary indicators, regulating standard procedures, selecting proper evaluators especially the outsiders, improving public participation, making relevant laws or rules, etc. In addition, Jiangsu Provincial Government should get rid of the stereotyped ideas of performance measurement. Instead, it must transfer from the notion "measurement as management" to "measurement for improvement", meanwhile from "traditional controlling model" to "government reinvention model". In other words, the provincial government should rethink the function of government performance measurement, which is not only viewed as a useful tool of administration management, but also as an essential channel to lead to significant improvement of performance. Furthermore, the higher level government should not rely on using performance measurement to control lower level governments so as to implement the commands; on the contrary, by introducing performance measurement, especially with increased public participation and stricter legal procedures, the higher level government should stress on reinventing governmental accountability and functions. If this is done in the coming practice, the government performance measurement will move into a new phase in Jiangsu. There is substantial room for performance management improvement left in nearly all state/provincial level governments in China, USA, or all other countries.

\section{References}

Aristigueta, M. P. (1999). Managing for results in state government. Westport, CT: Connecticut.

Baidu. (2013). Jiangsu. Retrieved from http://baike.baidu.com/view/4141.htm?fromId=16156

Bao, C. L., Chen, J. H., \& Jiang, J. K. (2008). Review and outlook on the government performance measurement in China. Chinese Personnel Reporting. Retrieved from http://www.rky.org.cn/c/cn/news/2008-10/27/news_6464.html

Bouckaert, G., \& Halligan, J. (2008). Managing performance, international comparisons. London and New York: Routledge. P. 18.

Bush, G. W. (2001). President's Management Agenda (PMA). Retrieved from http://archive.hhs.gov/pma/

Chinese Public Administrative Society Research Group. (2006). Research report of government performance measurement. Retrieved from http://www. People daily.net 
Gong, L. G. (2006). Introduction of practical models of Chinese public sector performance measurement. Chinese Public Administration. Chinese Public Administration Society Research Group. Pp. 11-16.

Hatry, H. P. (1980). Performance measurement principles and techniques, an overview for local government. In R. C. Kearney and E. M. Berman (Eds.), Public sector performance (p. 304). Boulder, Colorado: Westview Press.

Hatry, H. P. (2006). Performance measurement-Getting results (2nd ed.). Washington, D.C.: The Urban Institute Press.

Henry, N. (2010). Public administration and public affairs (11th ed.). New York: Longman.

Joyce, P. (2011). Obama's performance measurement agenda. Will the president's performance measurement efforts be used to balance the budget, or to fund successful programs? Retrieved from http:/www.governing.com/columns/mgmt-insights/ obama-performance-measurement-agenda.html

Kearney, R. C., \& Berman, E. M. (1999). Public sector performance, management, motivation, and measurement. An ASPA Classic Volume. Westview Press. Pp. 1-2.

Liu, K. J. (2009). Review on the research of government performance management. The forum of personnel issues, no. 44. Retrieved from http://www.mmrs.gov.cn

Lynch, T. D. (1994). Public budgeting in America. Englewood Cliffs, NJ: Prentice Hall.

Marr, B. (2009). Managing and delivering performance-How government, public sector and not-for-profit organizations can measure and manage what really matters. Butterworth-Heinemann. Pp. 1-3.

Ministry of Supervision. (2011). Ms. Ma Wen attended the Inter-Ministry Government Performance Management Working Conference and delivered a key note speech. Retrieved from http://www.360doc.com/content/11/0428/21/26005_113017936.shtml

Ministry of Supervision. (2012). Ms. Ma Wen attended the Inter-Ministry Government Performance Management Working Conference and delivered a key note speech. Retrieved from http://www.mos.gov.cn/mos/cms/html/3/21/201208/20706.html

Moynihan, D. P. (2008). The dynamics of performance management constructing information and reform. Washington, D.C.: Georgetown University Press.

OMB (Office of Management and Budget). (2007). OMB's Program Assessment Rating Tool (PART). Retrieved from http://strategisys.com/omb_part

People's Daily. (2011). From self exploration to conduct pilot project, the speeding up of institutional construction of government performance management. Retrieved from http://www.gov.cn/jrzg/2011-09/06/content_1940916.htm

Perez, T., \& Rushing, R. (2007). The CitiStat model: How data-driven government can increase efficiency \& effectiveness. Center for American Progress. Retrieved from http:/www.americanprogress.org/wp-content/uploads/issues/2007/04/pdf/ citistat_report.pdf

PMA (President's Management Agenda). (2001). President's Management Agenda (PMA). Retrieved from http://archive. hhs.gov/pma/

Qi, Y. (2007). Foreign comparison to Chinese system of government performance measurement indicators. People's Forum Magazine, Serial No. 257. Retrieved from http://teachingamerican history/org/library/index.asp?document=465

Radin, B. A. (2006). Challenging the performance movement: Accountability, complexity, and democratic values. Washington, D.C.: Georgetown University Press.

Research Group. (2010). Existing problems and possible solutions: Performance appraisal of leaders. Retrieved from http://www.ppirc.org/html./71/n-3071.html

Schedler, K. (1998). Performance measurement. In J. M. Shafritz (Ed.), International encyclopedia of public policy and administration (pp. 1634-1638). Boulder, Colorado: Westview Press.

Shang, Z. L. (2009a). Evaluation report on the administrative performance of China. Chinese local governments performance measurement research panel. Beijing: The Central Party School Publishing House. P. 51, pp.191-192, p. 276.

Shang, Z. L. (2009b). The outbreak of administrative reform. Outlook Magazine Weekly, pp. 20-21.

Smith, D. C., \& Bratton, W. J. (2001). Performance management in New York City: CompStat and the revolution in police management. In D. W. Forsythe (Ed.), Quicker better cheaper? Managing performance in American government. Albany: The Rockefeller Institute Press.

Tan, Z. J. (2009). Enlightenment of American government performance measurement to China. Chinese Economy and Management Science, 5, 20-22.

The National Association of State Budget Officers (NASBO). (2008). Budget processes in the states. Retrieved from http://www.nasbo.org/publications-data/budget-processes-in-the-states

Vozzella, L. (2004). CitiStat wins prize honoring innovation. O'Malley to accept award via satellite from Boston. Retrieved from http://articles.baltimoresun.com/2004-07-28/news/0407280194_1_omalley-government-award 
Wang, T. K., \& Rao, C. L. (2011). A comparison of U.S. and Chinese performance measurement legislation. Chinese Public Administration Review, 6(3/4), 13-23.

Wilson, W. (1887). The study of administration. In J. M. Shafritz and A. C. Hyde (Eds.), Classics of public administration (6th ed.) (pp. 16-27). Belmont, California: Thomson Wadsworth.

Wu, R. J. (2008). Problem and outlet: Chinese local government performance measurement. Retrieved from http://www.pbgchina. $\mathrm{cn} /$ newsinfo.asp?newsid $=3637$

Xie, B. H. (2008). Ten thousand citizen participation of government performance measurement: The initial exploration of new way of performance measurement for Chinese local party and government branches. Beijing: Peking University Press.

Yin, R. K. (2009). Case study research: Design and methods (4th ed.). Woburn, Massachusetts: Sage Publications.

Zheng, F. H., \& Duan, J. (2012). Provincial level "government performance assessment" model comparison. Chinese Public Administration, 321(3), 34-38.

\section{Appendix 1: Questionnaire (English edition)}

\section{Questionnaire of Government Performance Measurement}

(For most questions below, you can choose more than one possible answer from the first to the fifth alternatives)

1. When did you get to know the notion of government performance measurement?

(a) lately, (b) two years ago, (c) around 2004, (d) around 2001, (e) a long time ago, (f) not sure

2. Have you ever heard of something about government performance measurement in Jiangsu Province?

(a) about Nanjing Municipal Government's practice, (b) about Nantong Municipal Government's practice, (c) about Suzhou Municipal Government's practice, (d) about Shuqian Municipal Government's practice, (e) about the Provincial Government's practice, (f) not sure

3. Have you ever heard of something about government performance measurement in China?

(a) about practice of the Organization Department of CPC Central Committee, (b) about practice of the Personnel Department, (c) about practice of the Ministry of Finance, (d) about practice of the State Council, (e) about practice of the Committee of Development and Reform Committee, (f) not sure

4. Have you ever heard of something about government performance measurement in other provinces (or metropolis) of China?

(a) about practice of Shanghai, (b) about practice of Shandong, (c) about practice of Gansu, (d) about practice of Jilin, (e) about practice of Shenzhen, (f) not sure

5. Have you ever heard of something important about government performance measurement in the world?

(a) about practice of the USA, (b) about practice of the UK, (c) about practice of Australia, (d) about practice of Singapore, (e) about practice of Germany, (f) not sure

6. How do you judge the practice of government performance measurement during the three decades recently in USA? Which one ranks the best in terms of promotion and implementation of performance measurement?

(a) Reagan administration, (b) Bush (Senior) administration, (c) Clinton administration, (d) Bush (Junior) administration, (e) Obama administration, (f) not sure

7. Do you know the basic goal of performance measurement across the world?

(a) to save administrative costs, (b) to promote government efficiency, (c) to improve the quality of public services, (d) to facilitate the process of democracy, (e) to introduce public supervision, (f) not sure

8. Do you know the basic goal of performance measurement in China?

(a) to assess personnel achievements, (b) to promote government efficiency, (c) to improve public services, (d) to construct responsibility-typed government, (e) to reinforce clear-government construction, (f) not sure

9. How do you think of the significance and effect of government performance measurement? 
(a) extremely important, (b) important, (c) generally important, (d) not important, (e) not so much important, (f) not sure

10. How do you think of the relationship between the evaluation of administrative discipline \& work ethic of government employees and government performance measurement?

(a) very tightly related, (b) tightly related, (c) somehow related, (d) not related, (e) not so much related, (f) not sure

11. How do you think of the relationship between the evaluation of outcome of "well-off society construction" and government performance measurement?

(a) very tightly related, (b) tightly related, (c) somehow related, (d) not related, (e) not so much related, (f) not sure

12. How do you feel about the effect which the evaluation of administrative discipline \& work ethic of government officials has brought in efficiency-improvement in provincial government agencies?

(a) very significant, (b) significant, (c) moderately significant, (d) not significant, (e) not so much significant, (f) not sure

13. How do you feel about the effect which the evaluation of "well-off society construction" has resulted in promoting performance of municipal and county governments?

(a) very significant, (b) significant, (c) moderately significant, (d) not significant, (e) not too much significant, (f) not sure

14. How do you feel about the participation of ordinary people in evaluating administrative discipline \& work ethic of government officials?

(a) very actively, (b) actively, (c) moderately actively, (d) not actively, (e) not too much actively, (f) not sure

15. How do you think of consistency between the indicators of "well-off society construction" and people's satisfaction?

(a) very tightly related, (b) tightly related, (c) somehow related, (d) not related, (e) not too much related, (f) not sure

16. What is your opinion about the attitude of municipal and county government towards cultivation of administrative discipline \& work ethic in provincial government?

(a) very satisfactory, (b) satisfactory, (c) moderately satisfactory, (d) not so much satisfactory, (e) strongly dissatisfactory, (f) not sure

17. What is your opinion about the attitude of ordinary people towards the progress of administrative discipline \& work ethic construction in provincial government agencies?

(a) very satisfactory, (b) satisfactory, (c) moderately satisfactory, (d) not so much satisfactory, (e) strongly dissatisfactory, (f) not sure

18. If it is evaluated in terms of 100 marks, what level of score will be given to the performance of "administrative discipline \& work ethic construction" in provincial government agencies according to your personal assessment?

(a) full marks, (b) excellent, (c) good, (d) passed, (e) failed, (f) not sure

19. What's your opinion about the real effect which the "welfare society construction" evaluation has produced on the government officials who work at municipal and county governmental levels?

(a) very significant, (b) significant, (c) moderately significant, (d) not significant, (e) not so much significant, (f) not sure

20. What is the real familiarity which the ordinary people exhibit on the indicator system of "welfare society construction" evaluation?

(a) very familiar, (b) familiar, (c) moderately familiar, (d) unfamiliar, (e) very unfamiliar, (f) not sure

21. If it is evaluated in terms of 100 marks, what level of score will be given to the performance of "welfare society construction" from your personal perspective?

(a) full marks, (b) excellent, (c) good, (d) passed, (e) failed, (f) not sure

22. The administrative region (or government agency) where you are currently working has introduced:

(a) government performance measurement, (b) administrative discipline \& work ethic construction evaluation in government agency, (c) annual assessment on the situation of social and economic development, (d) promotion of government efficiency, (e) 
assessment on targeted-objective annually, (f) not sure

23. What is the relationship between the assessment which is undertaking in your administrative region (or government agency) and the evaluation of "administrative discipline \& work ethic construction" in provincial government agencies?

(a) very tightly related, (b) tightly related, (c) a little related, (d) unrelated, (e) very unrelated, (f) not sure

24. What is the relationship between the assessment which is undertaking in your administrative region (or government agency) and the evaluation of "welfare society construction"?

(a) very tightly related, (b) tightly related, (c) a little related, (d) unrelated, (e) very unrelated, (f) not sure

25. What's your expectation on the government performance measurement in Jiangsu Province in the future?

(a) implemented annually, (b) implemented once within two years, (c) implemented irregularly depending on the real situation, (d) implemented or not, (e) no need to implement, (f) not sure

26. What's your expectation on the government performance measurement in your administrative region (or government agency) in the future?

(a) implemented annually, (b) implemented once within two to three years, (c) implemented irregularly depending on the real situation, (d) implemented or not, (e) no need to implement, (f) not sure 